\title{
Seroprevalence and factors associated with hepatitis $B$ infection among the hill tribe adult population in Thailand: a cross- sectional study
}

Panupong Upala ${ }^{1}$, Tawatchai Apidechkul ${ }^{1,2^{*}}$ D, Ratipark Tamornpark ${ }^{1}$, Chalitar Chomchoei $^{3}$ and Fartima Yeemard ${ }^{1}$

\begin{abstract}
Background: Hepatitis B virus (HBV) infection is one of the greatest public health burdens, particularly for people living with several barriers to access to health care services, such as the hill tribe adult population in Thailand. People aged 25 years and over who are out of the target population for HBV immunization under the national Expanded Program on Immunization (EPI) are at risk of HBV infection. The study aimed to estimate the prevalence and determine the factors associated with HBV infection among hill tribe adults aged 25 years and over living in Chiang Rai Province, Thailand.
\end{abstract}

Methods: A cross-sectional study design was used to collect information on hill tribe adults aged 25 years and over living in 36 selected hill tribe villages in Chiang Rai Province. All people living in the selected villages who met the criteria were invited to participate in the study. A validated questionnaire and a $5-\mathrm{mL}$ blood specimen were used as research instruments. Hepatitis B surface antigen (HBsAg), antibody to hepatitis B surface (anti-HBs), and antibody to hepatitis B core (anti-HBC) were detected by using the Wondfo Test Kit ${ }^{@}$, which has high sensitivity and specificity. Logistic regression was used to detect the associations between variables at the significance level of $a=0.05$.

(Continued on next page)

\footnotetext{
* Correspondence: Tawatchai.api@mfu.ac.th; tk2516ms@gmail.com

${ }^{1}$ Center of Excellence for The Hill tribe Health Research, Mae Fah Luang University, Chiang Rai, Thailand

${ }^{2}$ School of Health Science, Mae Fah Luang University, 333 Mo.1 Tasud

Sub-district, Muang District, Chiang Rai 57100, Thailand

Full list of author information is available at the end of the article
}

(c) The Author(s). 2020 Open Access This article is licensed under a Creative Commons Attribution 4.0 International License, which permits use, sharing, adaptation, distribution and reproduction in any medium or format, as long as you give appropriate credit to the original author(s) and the source, provide a link to the Creative Commons licence, and indicate if changes were made. The images or other third party material in this article are included in the article's Creative Commons licence, unless indicated otherwise in a credit line to the material. If material is not included in the article's Creative Commons licence and your intended use is not permitted by statutory regulation or exceeds the permitted use, you will need to obtain permission directly from the copyright holder. To view a copy of this licence, visit http://creativecommons.org/licenses/by/4.0/. The Creative Commons Public Domain Dedication waiver (http://creativecommons.org/publicdomain/zero/1.0/) applies to the data made available in this article, unless otherwise stated in a credit line to the data. 
(Continued from previous page)

Results: A total of 1491 individuals were recruited into the analysis; 60.8\% were females, $81.3 \%$ were aged between 30 and 60 years, and $86.0 \%$ were married. The majority were illiterate (54.9\%), were Buddhist (55.7\%), worked in agricultural sectors (87.3\%), and had an annual income of less than 50,000 baht per year (72.9\%). The overall prevalence of hepatitis B infection was 26.6\%; 7.6\% were positive for HBsAg, 19.2\% were positive for anti-HBs, and $18.9 \%$ were positive for anti-HBc. In the multivariate analysis, three variables were found to be associated with hepatitis B infection: those who were in the Yao and Lisu tribes had a 1.64-fold (95\% Cl=1.08-2.49) and a 1.93-fold (95\% Cl $=1.10-3.31)$ greater chance, respectively, of HBV infection than did those in the Karen tribe; those who were Christian had a 1.41 -fold $(95 \% \mathrm{Cl}=1.06-1.87)$ greater chance of HBV infection than did those who were Buddhist; and those who did not use alcohol had a 1.29-fold (95\% Cl $=1.01-1.65)$ greater chance of HBV infection than did those who used alcohol.

Conclusions: It is necessary to develop and implement effective public health interventions among hill tribe adult populations who are not part of the EPI-targeted population, particularly Christians, those in the Lisu and Yao tribes, and those who do not use alcohol, to reduce the HBV infection rate, save lives and reduce medical expenses.

Keywords: Seroprevalence, Hepatitis B virus, Factor associated, Hill tribe, Adults

\section{Background}

Hepatitis B virus infection is the greatest infectious disease in the human population, with approximately 257 million people living with chronic hepatitis B infection, which is defined by HBsAg positivity globally [1]. It is a common infectious disease that is transmitted person-to-person during delivery [2] and through contaminated blood [3] and other body fluids [2]. The targeted organ of the infection is the human liver [4]. Afterward, wide ranges of pathogenesis and complications could occur to adversely affect the infected liver's health [5]. The serious final stage of infection is cancer, which mostly presents as aggressive progression for the organ with a very poor prognosis [6]. The WHO estimated that 887,000 deaths are reported every year from cirrhosis and hepatocellular carcinoma resulting from hepatitis $\mathrm{B}$ infection [1]. The WHO also reported that the highest prevalence of hepatitis $\mathrm{B}$ infection was in the Asia Pacific region (6.2\%) [1]. A total of US $\$ 58.7$ billion is needed to address hepatitis among 67 low- and middle-income countries by 2030, which could prevent $90.0 \%$ of new cases of infection and save the lives of $65.0 \%$ of those with existing cases of infection, including individuals in Thailand [7].

Thailand reported 2.2-3 million people who were hepatitis B carriers and who were HBsAg positive [8]. Thailand has included the hepatitis $B$ vaccine on one of the lists in the Expended Program on Immunization (EPI) for almost 25 years since it was first implemented in 1992. Since then, this program has reduced the $\mathrm{HBV}$ carrier rate among children aged younger than 25 years by less than $1.0 \%$. However, a high prevalence of those aged 25 years and older were still reported to be carriers of hepatitis B, with an average of $5.9 \%$ [9]. The hepatitis B vaccine has significantly reduced the number of hepatitis carriers and other medical expenses and has been used for treatment and care related to hepatitis $B$ viral infection in the Thai population. However, this does not mean that all Thai people can access health care services equality, especially immunizations for children and other targeted populations under the national EPI, even if they do not need to pay a fee [10]. In addition, those who do not fall within the target of the Thai national EPI are requested to pay for US\$70 for each $\mathrm{HBV}$ vaccine (three standard doses) [11]. Some Thai people live in poor economic conditions, have low levels of education and face several barriers to access to medical services, such as language, distance, and stigmatization [12].. The hill tribe people are a good example of those with atypical access to Thai medical services, since they are living in rural areas and have specific cultures and perceptions, particularly with unrespect to access to medical services, including immunization for children [13-15].

The hill tribe people migrated from southern China and settled down along the borders of ThailandMyanmar-Laos over a couple centuries [16]. They are now composed of six main tribes: Akha, Lahu, Hmong, Yao, Karen, and Lisu [16]. In 2019, approximately 2.5-3.5 million people lived in Thailand [15], and 250,000-350,000 people lived in Chiang Rai Province [17]. Approximately $70.0 \%$ [18] of the hill tribe people have Thai identification cards (IDs), which are used for access to all public services, including health care services [19].

Unfortunately, the hill tribe people are living in the era of HBV vaccine implementation in Thailand, but the prevalence estimates of hepatitis B surface carrier (HBsAg) and the total hepatitis $\mathrm{B}$ infection were reported to be higher among the hill tribe people than in 
the Thai population in the same age category at $10.3 \%$ [20]. With the specific history of those in the hill tribes who migrated from China, which has the highest prevalence of hepatitis $B$ infection in the world [21], and given these individuals' very limited access to health care services, the hill tribe population in Thailand is at risk of hepatitis B infection. Moreover, lifestyles and practices such as ear piecing [22], high alcohol consumption [23] and other substance use, including drug injection by untrained health professionals [24], all while living far away from the city, could lead individuals to become vulnerable to hepatitis B infection.

There is no scientific information regarding hepatitis B infection in the hill tribe population aged 25 years and older before the generation of the hepatitis $B$ vaccine implementation in Thailand. Thus, the study aimed to estimate the prevalence of hepatitis B infection by detecting hepatitis B surface antigen ( $\mathrm{HBsAg}$ ), antibody to hepatitis B surface (anti-HBsAg), and total antibody to hepatitis $\mathrm{B}$ core (anti-HBc) according to the standard guidelines of the Centers for Disease Control and Prevention (CDC, US) [25].

\section{Methods}

\section{Study design}

A community-based cross-sectional study was used to collect information from the participants.

\section{Study settings}

The study was conducted in the hill tribe villages in Chiang Rai Province, Thailand. There are six main hill tribes living in the study settings: Akha, Lahu, Hmong, Yao, Karen, and Lisu. In 2019, there were 749 hill tribe villages in Chiang Rai, which included 316 Lahu villages, 243 Akha villages, 63 Yao villages, 56 Hmong villages, 36 Karen villages, and 35 Lisu villages [17]. Six villages in each tribe were randomly selected to be study settings from the lists of the hill tribe villages in 2019 [17]; therefore, 36 hill tribe villages located in 14 districts in Chiang Rai Province served as the study settings [17].

\section{Study population}

The study population included hill tribe people who lived in the selected villages and met the eligibility criteria. The eligibility criteria for the study were as follows: i) belonging to one of the six main hill tribes in Thailand, ii) able to provide essential information according to the study protocol, and iii) aged 25 years and over.

\section{Study sample and sample size calculation}

The sample size was calculated from the standard formula of a cross-sectional study $(\mathrm{Z}=1.96, P=0.13$ [20], $\mathrm{Q}=0.87$ and $\mathrm{e}=0.05$ ); therefore, at least 246 participants in each tribe were required for the analysis. Thus, a minimum of 1475 participants were needed in the whole study.

\section{Research instruments and their development}

The questionnaire was developed from the literature review and was discussed with the medical staff working in an infectious diseases clinic at the Chiang Rai Regional Hospital (a tertiary hospital). The content validity of the questionnaire was also determined by the itemobjective congruence (IOC) technique by three external experts (one epidemiologist, one public health specialist, and one infectious diseases physician), who provided their opinions regarding the relevance of the questions and the content of the study. The questions scoring less than 0.50 were excluded from the questionnaire set, those scoring between $0.51-0.70$ were revised as comments obtained by the experts, and those scoring equal or more than 0.71 were included in the set of questionnaires.

Afterwards, the feasibility and ordering of the questions on the questionnaire were determined through its piloting in 15 samples with characteristics similar to those of the study participants at Mae Chan Hospital, Chiang Rai Province, Thailand. After the questionnaire was revised following the pilot test, the final questionnaire consisted of three parts. Part one included 10 questions that were used to collect the sociodemographic characteristics of the participants, such as age, sex, religion, marital status, occupation, and income. Part two included 14 questions that were used to collect information on risk behaviors related to hepatitis B infection, such as alcohol use, methamphetamine use, tattooing, history of blood transfusion, history of organ transplantation, and history of hepatitis $B$ vaccination. Three open-ended questions were provided to collect laboratory results.

\section{Data collection procedure}

After approval was obtained for the research ethical consideration, development and completion of the questionnaire, all 14 relevant district government officers were contacted by the researchers to obtain their approval for access to the villages. Afterward, village headmen were contacted and were provided with details on the study. Targeted populations who met the criteria were informed regarding the execution of the study and made appointments for data collection 3 days prior. 
Table 1 General characteristics of participants

\begin{tabular}{lll}
\hline Characteristic & Number & Percent \\
\hline Total & 1491 & 100.0 \\
Sex & & \\
$\quad$ Male & 585 & 39.2 \\
$\quad$ Female & 906 & 60.8 \\
Age (years) & & \\
$\quad<30$ & 66 & 4.4 \\
$30-60$ & 1212 & 81.3 \\
$>60$ & 213 & 14.3
\end{tabular}

Mean $=48.9$ years, $S D=11.0, \operatorname{Min}=25, \operatorname{Max}=78$

\section{Marital status}

Single

Married

Ever married

\section{Education}

|lliterate

Primary school

Secondary school

High school and above

\section{Religion}

Buddhist

Christian

Tribe

Akha

Lahu

Hmong

Yao

Lisu

Karen

Having Thai ID card

Yes

No

71

Occupation

Farmer

Working in a trade

Daily wage employee

Right to access free health care services

Thai universal health scheme

State enterprise officer

Social security scheme

Private insurance

No

Number of family members (persons)

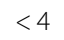

Table 1 General characteristics of participants (Continued)

\begin{tabular}{lll}
\hline Characteristic & Number & Percent \\
\hline$>7$ & 170 & 11.4 \\
Annual income (baht) & & \\
$\quad<10,000$ & 158 & 10.6 \\
$10,001-50,000$ & 929 & 62.3 \\
$>50,000$ & 404 & 27.1 \\
\hline
\end{tabular}

On the date of data collection, all participants were asked to obtain the informed consent form after providing all essential information for the study, followed by $5-\mathrm{mL}$ blood specimens being drawn by licensed health professionals. The questionnaire was completed by self-administration in a private and confidential room. Those who could not understand Thai received assistance in completing the questionnaire by village public health volunteers who were fluent in both Thai and local languages. All processes lasted for $30 \mathrm{~min}$ each.

\section{Laboratory methods}

Five-milliliter blood specimens were drawn from all participants. The laboratory analysis for hepatitis B markers $\mathrm{HBsAg}$, anti-HBs, and total anti-HBc was performed at the Mae Fah Luang Central Medical Laboratory on the same day that blood specimens were drawn by licensed medical technicians.

The Wondfo One Step HBsAg Serum/Plasma ${ }^{@}$ was used for the detection of HBsAg. It has $96.2 \%$ sensitivity and 99.3\% specificity. The Wondfo Diagnostic Kit ${ }^{@}$ was used for the detection of anti-HBs and total anti-HBc, with $97.3 \%$ sensitivity and $99.2 \%$ specificity.

\section{Outcomes}

Hepatitis B infection was defined based on the standard guideline for the interpretation of hepatitis B serologic test results of the Centers for Disease Control and Prevention $(C D C)$, United States [25], such that those who were positive for either or both HBsAg and anti-HBs, except for those who had a negative anti-HBc, were considered to have hepatitis B infection.

\section{Statistical analysis}

Data were double-entered into an Excel sheet and checked for errors before being transferring into SPSS program version 24 (SPSS, Chicago, IL) for analysis. Continuous and categorical data were described properly to present the general characteristics of the participants and their behaviors, including hepatitis B biomarkers. Logistic regression was used to identify the factors associated with hepatitis $B$ infection at the significance level of $\alpha=0.05$. 
Table 2 Identifications of health behaviors by sex

\begin{tabular}{|c|c|c|c|c|c|c|c|}
\hline \multirow[t]{2}{*}{ Health behaviors } & \multicolumn{2}{|l|}{ Total } & \multicolumn{2}{|l|}{ Male } & \multicolumn{2}{|c|}{ Female } & \multirow{2}{*}{$\begin{array}{l}x^{2} \\
(p-\text {-value })\end{array}$} \\
\hline & $n$ & $\%$ & $n$ & $\%$ & $n$ & $\%$ & \\
\hline \multicolumn{8}{|l|}{ Alcohol use } \\
\hline No & 927 & 62.2 & 370 & 63.2 & 557 & 61.5 & \multirow[t]{2}{*}{$0.47(0.492)$} \\
\hline Yes & 564 & 37.8 & 215 & 36.8 & 349 & 38.5 & \\
\hline \multicolumn{8}{|l|}{ Methamphetamine use } \\
\hline No & 1441 & 96.6 & 567 & 96.9 & 874 & 96.5 & \multirow[t]{2}{*}{$0.23(0.634)$} \\
\hline Yes & 50 & 3.4 & 18 & 3.1 & 32 & 3.5 & \\
\hline \multicolumn{8}{|l|}{ Heroin use } \\
\hline No & 1484 & 99.5 & 581 & 99.3 & 903 & 99.7 & \multirow[t]{2}{*}{$0.95(0.331)$} \\
\hline Yes & 7 & 0.5 & 4 & 0.7 & 3 & 0.3 & \\
\hline \multicolumn{8}{|l|}{ Opium use } \\
\hline Yes & 1440 & 96.6 & 559 & 95.6 & 881 & 97.2 & \multirow[t]{2}{*}{$3.01(0.080)$} \\
\hline No & 51 & 3.4 & 26 & 4.4 & 25 & 2.8 & \\
\hline \multicolumn{8}{|l|}{ Marijuana use } \\
\hline Yes & 1460 & 97.9 & 571 & 97.6 & 889 & 98.1 & \multirow[t]{2}{*}{$0.47(0.495)$} \\
\hline No & 31 & 2.1 & 14 & 2.4 & 17 & 1.9 & \\
\hline \multicolumn{8}{|l|}{ Tattooed } \\
\hline No & 1317 & 88.3 & 464 & 79.3 & 853 & 94.2 & \multirow[t]{2}{*}{$75.88\left(<0.001^{\mathrm{a}}\right)$} \\
\hline Yes & 174 & 11.7 & 121 & 20.7 & 53 & 5.8 & \\
\hline \multicolumn{8}{|l|}{ Ear piercing } \\
\hline No & 699 & 46.9 & 504 & 86.2 & 195 & 21.5 & \multirow[t]{2}{*}{$596.26\left(<0.001^{\mathrm{a}}\right)$} \\
\hline Yes & 792 & 53.1 & 81 & 13.8 & 711 & 78.5 & \\
\hline \multicolumn{5}{|l|}{ History of blood transfusion } & 881 & 60.9 & \\
\hline No & 1446 & 97.0 & 565 & 96.5 & 881 & 97.2 & \multirow[t]{2}{*}{$0.53(0.467)$} \\
\hline Yes & 45 & 3.0 & 20 & 3.4 & 25 & 2.8 & \\
\hline \multicolumn{8}{|c|}{ History of organ transplantation } \\
\hline No & 1468 & 98.5 & 573 & 97.9 & 895 & 98.8 & $1.64(0.200)$ \\
\hline Yes & 23 & 1.5 & 12 & 2.1 & 11 & 1.2 & \\
\hline History of medical surgery & & & & & & & \\
\hline No & 1325 & 88.9 & 534 & 91.3 & 791 & 87.3 & $5.68\left(0.017^{\mathrm{a}}\right)$ \\
\hline Yes & 166 & 11.1 & 51 & 8.7 & 115 & 12.7 & \\
\hline Drug injection from unqualifi & profes & & & & & & \\
\hline No & 1442 & 96.7 & 559 & 95.6 & 883 & 97.5 & $4.06\left(0.044^{\mathrm{a}}\right)$ \\
\hline Yes & 49 & 3.3 & 26 & 4.4 & 23 & 2.5 & \\
\hline Acupuncture & & & & & & & \\
\hline No & 1377 & 92.4 & 544 & 93.0 & 833 & 91.9 & $0.55(0.457)$ \\
\hline Yes & 114 & 7.6 & 41 & 7.0 & 73 & 8.1 & \\
\hline Sharing toothbrush & & & & & & & \\
\hline No & 1384 & 92.8 & 527 & 90.1 & 857 & 94.6 & $10.84\left(0.001^{\mathrm{a}}\right)$ \\
\hline Yes & 107 & 7.2 & 58 & 9.9 & 49 & 5.4 & \\
\hline History of receiving $\mathrm{HBV}$ vacc & & & & & & & \\
\hline Yes & 78 & 5.2 & 113 & 19.3 & 140 & 15.5 & $4.55(0.208)$ \\
\hline No & 1059 & 71.0 & 313 & 53.5 & 515 & 56.8 & \\
\hline Not sure & 192 & 12.9 & 105 & 17.9 & 175 & 19.3 & \\
\hline Don't know & 162 & 10.9 & 54 & 9.2 & 76 & 8.4 & \\
\hline
\end{tabular}

${ }^{\mathrm{a}}$ Significance level at $\mathrm{a}=0.05$ 


\section{Results}

A total of 1491 individuals were recruited into the analysis; $60.8 \%$ were females, $81.3 \%$ were aged between 30 and 60 years, and $86.0 \%$ were married. The majority were illiterate (54.9\%), were Buddhist (55.7\%), worked in agricultural sections (87.3\%), and had an annual income of less than 50,000 baht per year (72.9\%). A large proportion held Thai ID cards (95.2\%) and had the right to access to free-of-charge care $(95.0 \%)$ (Table 1$)$.

One-third of the participants used alcohol (37.8\%), but a few people used other substances: amphetamine (3.4\%), heroin $(0.5 \%)$, opium (3.4\%), and marijuana (2.1\%). More than half of the participants had experienced ear piercing (53.1\%), and $11.3 \%$ were tattooed. A small proportion of individuals had experienced blood transfusion $(3.0 \%)$, organ transplantation $(1.5 \%)$, medical surgery (11.1\%), and acupuncture (7.6\%). Five (5) variables were found the statistical significances on the proportions in different health behaviors between sex; tattooed ( $p$-value $<0.001)$, ear piercing ( $\mathrm{p}$ value $<0.001$ ), history of medical surgery ( $\mathrm{p}$-value $=$ 0.017 ), drug injection from unqualified health professional $(\mathrm{p}$-value $=0.044)$, and sharing toothbrush $\mathrm{p}$ value $=0.001)$ (Table 2).

Among the 1491 participants, 113 (7.6\%) were positive for $\mathrm{HBsAg}$, $19.2 \%$ were positive for anti-HBs, and $18.9 \%$ were positive for anti-HBc. The overall prevalence of hepatitis B infection was $26.6 \%$ (396 out of 1489). Moreover, three participants were positive for both antiHBsAg and HBsAg. There were no statistical differences among the tribes on HBsAg, anti-HBs, and total antiHBc status (Table 3).

Seven (7) variables were found the statistical significance in having hepatitis $\mathrm{B}$ infection; age ( $p$-value $=$ $0.021)$, tribe $(\mathrm{p}$-value $=0.042)$, education $(\mathrm{p}$-value $=$
$0.006)$, occupation ( $\mathrm{p}$-value $=0.031)$, income $(\mathrm{p}$-value $=$ 0.008 ), history of having hepatitis $\mathrm{B}$ infection in family member $(p$-value $=0.049)$, and alcohol use $(p$-value $=$ 0.042) (Table 4).

In the univariate analysis, five variables were found to be associated with hepatitis B infection: tribe, religion, occupation, income, and alcohol use. However, in the multivariate analysis, after controlling for sex, age, marital status, education, and ID card, only three (3) variables remained associated with hepatitis $\mathrm{B}$ infection: tribe, religion, and alcohol use. Those who were in the Yao and Lisu tribes had a 1.64-fold (95\% CI $=1.08-2.49)$ and a 1.93 -fold (95\% CI $=1.10-3.41)$ greater chance, respectively, of HBV infection than did those in the Karen tribe. Those who were Christian had a 1.41-fold (95\% $\mathrm{CI}=1.06-1.87)$ greater chance of $\mathrm{HBV}$ infection than did those who were Buddhist. Those who did not use alcohol had a 1.29-fold (95\% CI $=1.01-1.65)$ greater chance of HBV infection than did those who used alcohol (Table 4).

\section{Discussion}

The hill tribe people aged 25 years and over who do not fall in the targeted area of HBV vaccination under the Thailand national EPI program have a high prevalence of HBV infection (26.6\%); this population also has a high prevalence of HBsAg carriers (7.6\%). The prevalence has increased according to the increase of age and income. Several risk behaviors affect the hill tribe population, including the use of various substances that could lead to HBV infection. However, individuals in certain tribes (Yao and Lisu), Christians and those who did not use alcohol were at a greater risk of $\mathrm{HBV}$ infection than others were.

The prevalence of $\mathrm{HBV}$ infection among the hill tribe adult populations was $26.6 \%$, and the hepatitis $B$

Table 3 Hepatitis B biomarkers in different tribes

\begin{tabular}{|c|c|c|c|c|c|c|c|c|c|c|c|c|c|c|c|}
\hline \multirow[t]{2}{*}{ Biomarkers } & \multicolumn{2}{|l|}{ Total } & \multicolumn{2}{|c|}{ Akha } & \multicolumn{2}{|c|}{ Lahu } & \multicolumn{2}{|c|}{ Hmong } & \multicolumn{2}{|l|}{ Yao } & \multicolumn{2}{|c|}{ Lisu } & \multicolumn{2}{|c|}{ Karen } & \multirow{2}{*}{$\begin{array}{l}x^{2} \\
(p \text {-value })\end{array}$} \\
\hline & $\mathrm{n}$ & $\%$ & $n$ & $\%$ & $n$ & $\%$ & $n$ & $\%$ & $n$ & $\%$ & $n$ & $\%$ & $n$ & $\%$ & \\
\hline \multicolumn{16}{|l|}{ HBsAg } \\
\hline Positive & 113 & 7.6 & 15 & 5.1 & 26 & 7.5 & 22 & 7.4 & 20 & 12.0 & 9 & 13.2 & 21 & 7.6 & $10.7(0.056)$ \\
\hline Negative & 1378 & 92.4 & 280 & 94.9 & 320 & 92.5 & 277 & 92.5 & 147 & 88.0 & 59 & 86.8 & 295 & 18.7 & \\
\hline \multicolumn{16}{|l|}{ Anti-HBs } \\
\hline Positive & 286 & 19.2 & 66 & 22.4 & 59 & 17.1 & 49 & 16.4 & 37 & 22.2 & 16 & 23.5 & 59 & 20.6 & $6.29(0.278)$ \\
\hline Negative & 1205 & 80.8 & 229 & 77.6 & 287 & 82.9 & 250 & 83.6 & 130 & 77.8 & 52 & 76.5 & 257 & 81.3 & \\
\hline \multicolumn{16}{|l|}{ Total anti-HBc } \\
\hline Positive & 283 & 18.9 & 66 & 22.4 & 58 & 16.7 & 48 & 16.0 & 37 & 22.2 & 16 & 23.5 & 58 & 18.4 & $7.07(0.215)$ \\
\hline Negative & 1208 & 81.1 & 229 & 77.6 & 288 & 83.3 & 251 & 84.0 & 130 & 77.8 & 52 & 76.5 & 258 & 81.6 & \\
\hline HBsAg-positive and anti-HBs-positive & 3 & 0.2 & 0 & 0.0 & 1 & 33.3 & 1 & 33.3 & 0 & 0.0 & 0 & 0.0 & 1 & 33.3 & N/A \\
\hline HBV infection & 396 & 26.6 & 81 & 20.5 & 84 & 21.2 & 70 & 17.7 & 57 & 14.4 & 25 & 6.3 & 79 & 19.9 & N/A \\
\hline
\end{tabular}


Table 4 Univarite and multivariate analyses in identification factors associated with hepatitis B infection

\begin{tabular}{|c|c|c|c|c|c|c|c|c|c|}
\hline \multirow[t]{2}{*}{ Factors } & \multicolumn{2}{|c|}{ Hepatitis B infection } & \multirow{2}{*}{$\begin{array}{l}x^{2} \\
(p \text {-value })\end{array}$} & \multirow[t]{2}{*}{ OR } & \multirow[t]{2}{*}{$95 \% \mathrm{Cl}$} & \multirow{2}{*}{$\begin{array}{l}\boldsymbol{p}^{-} \\
\text {value }\end{array}$} & \multirow[t]{2}{*}{$O R_{\text {Adj }}$} & \multirow[t]{2}{*}{$95 \% \mathrm{Cl}$} & \multirow{2}{*}{$\begin{array}{l}\boldsymbol{p} \text { - } \\
\text { value }\end{array}$} \\
\hline & $\begin{array}{l}\text { Yes } \\
\text { n (\%) }\end{array}$ & $\begin{array}{l}\text { No } \\
\text { n (\%) }\end{array}$ & & & & & & & \\
\hline \multicolumn{10}{|l|}{ Sex } \\
\hline Male & $150(25.6)$ & $435(74.4)$ & $0.42(0.519)$ & 0.93 & $0.73-1.17$ & 0.519 & & & \\
\hline Female & $246(27.2)$ & $660(72.8)$ & & 1.00 & & & & & \\
\hline \multicolumn{10}{|l|}{ Age (years) } \\
\hline$<30$ & $18(27.3)$ & $48(72.3)$ & $7.72\left(0.021^{\mathrm{a}}\right)$ & 1.00 & & & & & \\
\hline $30-60$ & $338(27.9)$ & $874(72.1)$ & & 1.03 & $0.59-1.80$ & 0.914 & & & \\
\hline$>60$ & $40(30.1)$ & $173(69.9)$ & & 0.62 & $0.33-1.17$ & 0.140 & & & \\
\hline \multicolumn{10}{|l|}{ Tribe } \\
\hline Akha & $81(27.5)$ & $214(72.5)$ & $11.50\left(0.042^{\mathrm{a}}\right)$ & 1.14 & $0.79-1.63$ & 0.490 & 1.08 & $0.73-1.59$ & 0.694 \\
\hline Lahu & $84(24.3)$ & $262(75.7)$ & & 0.96 & $0.68-1.37$ & 0.829 & 0.91 & $0.62-1.33$ & 0.623 \\
\hline Hmong & $70(23.4)$ & $229(76.6)$ & & 0.92 & $0.63-1.33$ & 0.646 & 0.99 & $0.67-1.46$ & 0.966 \\
\hline Yao & $57(34.1)$ & $110(65.9)$ & & 1.56 & $1.03-2.34$ & $0.034^{\mathrm{a}}$ & 1.64 & $1.08-2.49$ & $0.020^{\mathrm{a}}$ \\
\hline Lisu & $25(36.8)$ & $43(63.2)$ & & 1.74 & $1.00-3.04$ & $0.049^{\mathrm{a}}$ & 1.93 & $1.10-3.41$ & $0.023^{\mathrm{a}}$ \\
\hline Karen & $79(25.0)$ & $237(75.0)$ & & 1.00 & & & 1.00 & & \\
\hline \multicolumn{10}{|l|}{ Marital status } \\
\hline Married & $18(24.7)$ & $55(75.3)$ & $5.42(0.066)$ & 1.00 & & & & & \\
\hline Single & $353(27.5)$ & $929(72.5)$ & & 1.16 & $0.67-2.01$ & 0.592 & & & \\
\hline Ever married & $25(18.4)$ & $111(81.6)$ & & 0.69 & $0.35-1.37$ & 0.286 & & & \\
\hline \multicolumn{10}{|l|}{ Religion } \\
\hline Buddhism & $205(24.7)$ & $625(75.3)$ & $3.32(0.068)$ & 1.00 & & & 1.00 & & \\
\hline Christianity & $191(28.9)$ & $470(71.1)$ & & 1.24 & $1.01-1.56$ & $0.049^{\mathrm{a}}$ & 1.41 & $1.06-1.87$ & $0.017^{\mathrm{a}}$ \\
\hline \multicolumn{10}{|l|}{ Education } \\
\hline Illiterate & $198(24.2)$ & $621(75.8)$ & $12.28\left(0.006^{\mathrm{a}}\right)$ & 0.83 & $0.48-1.42$ & 0.496 & & & \\
\hline Primary school & $100(26.1)$ & $283(73.9)$ & & 0.92 & $0.52-1.62$ & 0.768 & & & \\
\hline Secondary school & 78 (35.9) & $139(64.1)$ & & 1.46 & $0.81-2.62$ & 0.206 & & & \\
\hline High school and above & $20(27.8)$ & $52(72.2)$ & & 1.00 & & & & & \\
\hline \multicolumn{10}{|l|}{ Having Thai ID card } \\
\hline Yes & $373(26.3)$ & $1047(73.7)$ & $1.30(0.254)$ & 1.00 & & & & & \\
\hline No & $23(32.4)$ & $48(67.6)$ & & 1.35 & $0.81-2.24$ & 0.156 & & & \\
\hline \multicolumn{10}{|c|}{ Having free access to health care services } \\
\hline Yes & $376(26.5)$ & $1044(73.5)$ & $0.10(0.753)$ & 1.00 & & & & & \\
\hline No & $20(28.2)$ & $51(71.8)$ & & 0.92 & $0.54-1.56$ & 0.761 & & & \\
\hline \multicolumn{10}{|l|}{ Occupation } \\
\hline Farmer & $345(24.5)$ & $957(73.5)$ & $6.97\left(0.031^{\mathrm{a}}\right)$ & 1.00 & & & & & \\
\hline Working in a trade & $16(44.4)$ & $20(55.6)$ & & 2.22 & $1.14-4.33$ & $0.019^{\mathrm{a}}$ & & & \\
\hline Daily wage employee & $35(22.9)$ & $118(77.1)$ & & 0.82 & $0.55-1.22$ & 0.335 & & & \\
\hline \multicolumn{10}{|c|}{ Number of family members (persons) } \\
\hline$<4$ & $202(27.9)$ & $523(72.1)$ & $1.39(0.499)$ & 1.00 & & & & & \\
\hline $4-7$ & $153(25.7)$ & $443(74.3)$ & & 0.89 & $0.70-1.14$ & 0.372 & & & \\
\hline$>7$ & $41(24.1)$ & $129(75.9)$ & & 0.82 & $0.56-1.21$ & 0.324 & & & \\
\hline \multicolumn{10}{|l|}{ Income (baht) } \\
\hline$<10,000$ & $45(28.5)$ & $113(71.5)$ & $9.65\left(0.008^{\mathrm{a}}\right)$ & 1.00 & & & & & \\
\hline $10,001-50,000$ & $222(23.9)$ & 707 (76.1) & & 0.78 & $0.54-1.15$ & 0.217 & & & \\
\hline$>50,000$ & $129(31.9)$ & $275(68.1)$ & & 1.18 & $0.79-1.76$ & 0.427 & & & \\
\hline
\end{tabular}


Table 4 Univarite and multivariate analyses in identification factors associated with hepatitis B infection (Continued)

\begin{tabular}{|c|c|c|c|c|c|c|c|c|c|}
\hline \multirow[t]{2}{*}{ Factors } & \multicolumn{2}{|c|}{ Hepatitis B infection } & \multirow{2}{*}{$\begin{array}{l}x^{2} \\
(p \text {-value })\end{array}$} & \multirow[t]{2}{*}{ OR } & \multirow[t]{2}{*}{$95 \% \mathrm{Cl}$} & \multirow{2}{*}{$\begin{array}{l}\boldsymbol{p} \text { - } \\
\text { value }\end{array}$} & \multirow[t]{2}{*}{$\mathrm{OR}_{\text {Adj }}$} & \multirow[t]{2}{*}{$95 \% \mathrm{Cl}$} & \multirow{2}{*}{$\begin{array}{l}\boldsymbol{p} \text { - } \\
\text { value }\end{array}$} \\
\hline & $\begin{array}{l}\text { Yes } \\
\text { n (\%) }\end{array}$ & $\begin{array}{l}\text { No } \\
\text { n (\%) }\end{array}$ & & & & & & & \\
\hline Yes & $13(54.5)$ & $38(74.5)$ & $0.03(0.860)$ & 0.94 & $0.50-1.79$ & 0.860 & & & \\
\hline No & $383(26.6)$ & $1057(73.4)$ & & 1.00 & & & & & \\
\hline \multicolumn{10}{|c|}{ Marijuana use } \\
\hline Yes & $5(16.1)$ & $26(83.9)$ & $1.77(0.184)$ & 0.53 & $0.20-1.38$ & 0.191 & & & \\
\hline No & 391 (26.8) & $1069(73.2)$ & & 1.00 & & & & & \\
\hline
\end{tabular}

${ }^{\mathrm{a}}$ Significance level at $\mathrm{a}=0.05$

surface carrier rate was $7.6 \%$, which are greater than the rates of these makers among the hill tribe aged 15-24 years, 3.0, 10.2, and 8.1\%, respectively [20]. This might be the impact of the HBV immunization implementation in Thailand which has been introduced since 1992 [26, 27]. The hepatitis B markers are greater that the corresponding rates found in a study conducted among the elderly population in northeastern Thailand [28]. A systematic review of the hepatitis $B$ infection rate in Thailand also reported that the overall prevalence rate was 5.1\% [29], which is lower than the prevalence in the hill tribe adult population. A study in Vietnam [30] reported a prevalence rate of $9.0 \%$ of $\mathrm{HBV}$, which was close to the rate among hill tribe adults in Thailand. The prevalence has increased according to age which is consisted with a study in China, [31, 32].

It is highly recommended that the HBV vaccine be implemented in high-prevalence areas by the United States Advisory Committee on immunization practice [27]. Therefore, Thailand needs to consider hepatitis $B$ vaccine implementation in the hill tribe adult population in Thailand, the benefits of which have been clearly demonstrated by the major economic gains realized from HBV immunization in Italy [33].

Another interesting point from the study is that $0.2 \%$ (3) of participants were reported to be positive for both HBsAg and anti-HBs among the hill tribe adults. This was explained by Lada et al. [34], who determined the influence of some determinant variants from viral mutations during chronic infection in the host organ.

Some tribes had a greater chance of hepatitis B virus infection than did others; for example, individuals from the Lisu or Yao tribes were at a greater risk of HBV infection than were those from the Karen tribe. This finding coincides with the findings of a study in Iran [35], which reported that some tribes living in rural areas were at a significantly greater risk of $\mathrm{HBV}$ than others were. Moreover, a study in Malaysia [36] also reported that individuals in some tribes in Malaysia had a rate of HBV infection that was higher than the national rate. Another study conducted in India [37] reported that different tribes who were living in eastern India had significantly different rates of $\mathrm{HBV}$ infection. A study in the United States [38] also demonstrated that some groups of people had a greater risk of $\mathrm{HBV}$ infection than others did. Apidechkul [20] also confirmed that some hill tribe youths had a greater chance of HBV infection than others did. While having looked more closely into some behaviors such as alcohol use, tattooed, and ear piecing, it was found that the Lisu (20.6\%) had a greater proportion of having tattooed than the Karen (17.7\%) and Yao (9.6\%), but the Yao (67.1\%) had a greater proportion of having ear piecing than the Karen (59.8\%) and Lisu (39.7\%). These might be the potential risk factors of hepatitis $B$ infection among the Lisu and Yao.

In the hill tribe population, adults who were Christians had a greater risk of hepatitis B infection than did those who were Buddhists. A study in Pakistan [39] reported that in some cultures, a reliance on religion may serve as a barrier to obtaining $\mathrm{HBV}$ vaccines, resulting in $\mathrm{HBV}$ infection. A study among Nigerian pregnant women [40] found that those following different religions had significantly different rates of HBV infection. In Thailand there is no evidence presented on restriction to access EPI program based on their religion. However, after taking a closer look into some variables in the participants' background, it was found that those who were Christians had a lower education that those who were Buddhists significantly $(p$-value $<0.001)$. This might be making them access to EPI program in different proportions, and resulting to have different risks of hepatitis $B$ infection. This association was supported by a study in China [41] and Malaysia [42].

Among the hill tribe adults, those who did not use alcohol had a greater risk of HBV infection than did those who used alcohol. This finding is not consistent with that of a study conducted in Korea [43], which clearly presented that those who had low levels of education tended to consume alcohol and develop HBV infection later. There are few studies on the association between alcohol use and HBV infection, but there are clear explanations for the association between alcohol use among 
those with hepatitis and the development of cirrhosis and hepatocellular carcinoma. Alcohol use might not the main route of $\mathrm{HBV}$ transmission among the hill tribe people in Thailand.

In our study, no participants refused to take part in the study. All participants who were positive for HBV biomarkers were informed to visit a medical doctor for proper treatment and care. Moreover, those who had a negative result for all HBV biomarkers were also asked to obtain the HBV vaccine from a health care provider properly and in a timely manner. The pattern of assessing exposures and outcomes in the same time on a cross-sectional study, it could impact the associations between variables while making interpretations [44]. Therefore, to make more clear on these associations, further stronger study designs to work out is recommended.

\section{Conclusion}

The hill tribe adult population aged 25 years and over with HBV who have never been immunized under the Thai national EPI program have low levels of education, live in poor economic conditions and reside in areas of Thailand with a high prevalence of hepatitis $B$ virus. They are highly vulnerable to hepatitis B infection, particularly those who are not using alcohol, Christians and those belonging to certain tribes, namely, the Lisu and Yao tribes. Effective public health interventions, including providing this population with $\mathrm{HBV}$ vaccines, need to be considered and implemented to reduce the HBV infection rate, save lives and decrease other medical costs.

\section{Abbreviations}

anti-HBc: Hepatitis B core antibody; anti-HBs: Hepatitis B surface antibody; CDC: Centers for Disease Control and Prevention; Cl: Confident interval; EPI: Expended Program on Immunization; HBV: Hepatitis B virus; HBsAg: Hepatitis B surface antigen; ID: Identification card; IOC: Item-Objective Congruence; SD: standard deviation; WHO: World Health Organization

\section{Acknowledgements}

We would like to thank Mae Fah Luang University, and The Center of Excellence for The Hill tribe Health Research for support grant. We also grateful for all participants for their participation the study.

\section{Authors' contributions}

PU: designed the study, collected data, laboratory analysis, analyzed data, and final proved manuscript; TA: designed the study, collected data, analyzed data, drafted manuscript, and final proved manuscript; RT, CC, FY: contacted the study settings, collected data, and final proved manuscript.

\section{Funding}

This study was supported grant from the Center of Excellence for the Hill tribe Health Research, Mae Fa Luang Thailand (Grant No. 21/2562).

\section{Availability of data and materials}

Data file is attached as supplement file. Additional data supporting these findings are available by personal request at Tawatchai.api@mfu.ac.th.

\section{Ethics approval and consent to participate}

All research protocols and tools were approved by the Chiang Rai Provincial Public Health Research Ethical Committee (No. CRPPHO 17/2562). All participants were asked to obtain written informed consent form after oral explanation on all essential information of the study, before starting of data collection.

\section{Consent for publication}

Not applicable.

\section{Competing interests}

The authors declare that they have no competing interests.

\section{Author details}

${ }^{1}$ Center of Excellence for The Hill tribe Health Research, Mae Fah Luang University, Chiang Rai, Thailand. ${ }^{2}$ School of Health Science, Mae Fah Luang University, 333 Mo.1 Tasud Sub-district, Muang District, Chiang Rai 57100,

Thailand. ${ }^{3}$ Chulabhorn Royal Academy, Bangkok, Thailand.

Received: 3 February 2020 Accepted: 2 July 2020

Published online: 10 July 2020

\section{References}

1. World Health Organization (WHO). Hepatitis B: fact sheets. Available from: https:/www.who.int/news-room/fact-sheets/detail/hepatitis-b. Accessed 18 Nov 2019.

2. World Health organization (WHO). Hepatitis B in the WHO European Region: fact sheet 2019. Available from: http://www.euro.who.int/_data/assets/pdf_ file/0007/377251/Fact-Sheet-Hepatitis-B_2019-ENG.pdf?ua=1. Accessed 18 Nov 2019

3. World Health Organization (WHO). Global hepatitis report, 2017. Available from: https://apps.who.int/iris/bitstream/handle/10665/255016/ 9789241565455-eng.pdf. Accessed 18 Nov 2019.

4. Centers for Disease Control and Prevention. Hepatitis B. Available from: https://www.cdc.gov/hepatitis/hbv/index.htm. Accessed 18 Nov 2019.

5. Chisari FC, Isogawa M, Wieland SF. Pathogenesis of hepatitis B virus infection. Pathol Biol (Paris). 2010;58(4):258-66.

6. Villanueva A. Hepatocellular carcinoma. N Engl J Med. 2019;380:1450-62.

7. World Health Organization (WHO). Hepatitis: WHO urges countries to invest in eliminating hepatitis. Available from: https://www.who.int/hepatitis/newsevents/who-urges-countries-invest-in-hepatitis/en/. Accessed 20 Nov 2019.

8. Ministry of Public Health. National health research plan 2019-2021. Available from: http:/www.oic.go.th/FILEWEB/CABINFOCENTER28/DRAWER068/ GENERAL/DATA0000/00000275.PDF. Accessed 20 Nov 2019

9. Posuwan N, Wanlapakorn N, Sa-nguanmoo P, Wasitthankasem R, Vichaiwattana $P$, Klinfueng $S$, et al. The success of a universal hepatitis $B$ immunization program as part of Thailand's EPI after 22 years' implementation. PlosOne. 2016;11(3):e0150499.

10. Pooripussarakul S, Riewpainoon A, Bishai D, Muangchana C, Tantivess S. What criteria do decision makers in Thailand use to set priorities for vaccine introduction? BMC Public Health. 2016;16(684). https://doi.org/10.1186/ s12889-016-3382-5.

11. Ministry of Public Health. National hepatitis B virus prevention and control plan 2017-2021. Available from: https://gnews.apps.go.th/news?news=443 71. Accessed 20 Nov 2019.

12. Apidechkul $\mathrm{T}$, Laingoen $\mathrm{O}$, Suwannaporn $\mathrm{S}$. Inequity in accessing health care service in Thailand in 2015: a case study of the hill tribe people in Mae Fah Luang district, Chiang Rai, Thailand. J Health Res. 2016;30(1):67-71.

13. Apidechkul T. A 20-year retrospective cohort study of TB infection among the hill tribe HIV/AIDS populations, Thailand. BMC Infect Dis. 2016;16:72. https://doi.org/10.1186/s12879-016-1407-4.

14. Tawatchai A. Prevalence of thalassemia carriers among the Lahu hill tribe population, Chiang Rai, Thailand. Asian Biomedicine. 2015;9(4):527-33.

15. Tawatchai A, Pilasinee W, Siriyaporn S, Thapakorn R. Health situation of Akha hill tribe in Chiang Rai province, Thailand. J Public Health Dev. 2016;14(1):77-97.

16. Princess Maha Chakri Siridhorn Anthropology center. Hill tribe. 2018. http:// www.sac.or.th/main/index.php. Accessed 21 Nov 2019.

17. The hill tribe welfare and development center, Chiang Rai province. Hill tribe population. The hill tribe welfare and development center. Chiang Rai: Ministry of Interior; 2019. p. 20-8. 
18. Apidechkul T, Wongnuch $P$, Sithisarn $S$, Ruanjai T. Health status of Akha hill tribe in Chiang Rai province, Thailand. J Pub Health Dev. 2016;14(1):77-97.

19. Department of Provincial Administration, Ministry of Interior, Thailand. Act on the card 2011. http://www.moi.go.th/portal/page?_pageid=814,103662 7,814_1036665\&_dad=portal\&_schema=PORTAL. Accessed 21 Nov 2019.

20. Apidechkul T. Seroprevalence and factors associated with hepatitis B virus infection among the hill tribe youths, northern Thailand. BMC Infect Dis. 2019;19(125). https://doi.org/10.1186/s12879-01903747-3.

21. Xu C, Chen T. Global prevalence of hepatitis B virus infection and prevention of mother-to-child transmission. Lancet Gastroenterol Hepatol. 2018;3(9):598-9.

22. Pichainarong $\mathrm{N}$, Chaveepojnkamjorn W, Luksamijarulkul P, Sujirarat D, Apidechkul T. Hepatitis B carrier among married hill tribe women in northern Thailand. Southeast Asian J Trop Med Public Health. 2003;34(1): 114-9.

23. Singkorn O, Apidechkul T, Putsa B, Detpetukyon S, Sunsern R, Thutsanti P, et al. Factors associated with alcohol use among Lahu and Akha hill tribe youths, northern Thailand. Substance Abuse Treatment Pfrevention Policy. 2019;14(5). https://doi.org/10.1186/s13011-019-0193-6.

24. Apidechkul T, Jiamton S, Jareinpituk S, Kaewkungwal J. Sexual behaviors and HIV infection among pregnant hill tribe women in northern Thailand. Southeast Asian J Trop Med Public Health. 2007;38(6):1061.

25. Centers for Disease Control and Prevention (CDC). Interpretation of hepatitis B serological results. Available from: https://www.cdc.gov/hepatitis/hbv/ pdfs/serologicchartv8.pdf. Accessed 21 Nov 2019.

26. Lana C, Sigrun R, Rania AT. Status and progress of hepatitis B control through vaccination in the South-East Asia region, 2992-2015. Vaccine. 2018; 36(1):6-14. https://doi.org/10.1016/j.vaccine.2017.11.027.

27. Schillie S, Vellozzi C, Reingold A, Harris A, Haber P, Ward JW, et al. Prevention of hepatitis B virus infection in the United States: recommendations of the advisory committee on immunization practices. Morbidity Mortality Weekly Report (MMWR). 2018;67(1):1-31.

28. Posuwan N, Vuthitanachot V, Chinchai T, Wasitthankasem R, Wanapakorn N, Poovorawa Y. Serological evidence of hepatitis a, B, and $C$ virus infection in older adults in Khon Kaen, Thailand and the estimated rate of chronic hepatitis B and C virus infection in Thais, 2017. Peer J. 2017;7:e7492.

29. Leroi C, Adam P, Khamduang W, Kawilapat S, Ngo-Giang-Huong N, Ongwandee $\mathrm{S}$, et al. Prevalence of chronic hepatitis B virus infection in Thailand: a systematic review and meta-analysis. Int J Infect Dis. 2016;51:3643.

30. Lee AW, Jacobs W, Chan E, Nguyen B, Hua DN, Ho JN, et al. Insight into hepatitis $B$ prevalence and risk factors among Vietnamese Americans: a cross-sectional analysis of data from a community-based screening program. BMJ Open. 2019;9:e029616. https://doi.org/10.1136/bmjopen-2019029616.

31. Lao T, Sahota DS, Law LW, Cheng Y, Leung TY. Age-specific prevalence of hepatitis B virus infection in young pregnant women, Hong Kong special administration region of China. Bull World Health Organ. 2014;92:782-9.

32. Sanai FM, Alghamdi H, Alswat KA, Babatin MA, Ismail MH, Alhamoudi WK, et al. Greater prevalence of comorbidities with increasing age: crosssectional analysis of chronic hepatitis B patients in Saudi Arabia. Saudi J Gastroenterol. 2019;5(3):194-200.

33. Boccalini S, Taddei C, Ceccherini V, Bechini A, Levi M, Bartolozzi D, et al. Economic analysis of the first 20 years of universal hepatitis $B$ vaccination program in Italy. Hum Vaccine Immunother. 2013;9(5):1119-28.

34. Lada O, Benhamou Y, Poynard T, Thibault V. Coexitence of hepatitis B surface antigen ( $\mathrm{HBsAg})$ and anti-HBs antibodies in chronic hepatitis $B$ virus carriers: influence of "a" determinant variants. J Virol. 2006;80(6):2968-75.

35. Ramya D, Subbiah R. Prevalence of hepatitis B and associated risk factors in irural tribal population. Asian J Pharm Clin Res. 2017;10(8). https://doi.org/10. 22159/ajpcr.2017.v10i8.18552

36. Sahlan N, Nor FM, Muslim A, Shaari SA, Rahman TH, Peng HB. Hepatitis B virus infection: epidemiology and seroprevalence rate amongst Negrito tribe in Malaysia. Med J Malaysia. 2019;74(4):320-5.

37. Dwibedi B, Sabat J, Ho LM, Singh SP, Sahu P, Arora R, et al. Moleculr epidemiology of hepatitis B virus in primitive tribes of Odsha, eastern India. Pathog Glob Health. 2014;108(8):362-8.

38. Kim H, Rotundo L, Yang J, Kim D, Kothari N, Feurdean M, et al. Racial/ethnic disparities in the prevalence and awareness of hepatitis $B$ virus infection and immunity in the United States. J Viral Hepat. 2017:24(11):1052-66.
39. Ali SA, Suhail N, Ali SA. Role of cultural and social barriers in increase burden of hepatitis B in Pakistan: literature review. J Infect Dis Diagnosis. 2016;1(2). https://doi.org/10.4172/2576-389X.1000105.

40. Mac PA, Suleiman AC, Airiohuodion PE. High prevalence of hepatitis B virus infection among pregnant women attending antenatal cate in center Nigeria, Journal of Infectious Disease and Epidemiology. 2019;5(1). https:// doi.org/10.23937/2474-3658/1510068.

41. Han Z, Yin Y, Zhang Y, Ehrhardt S, Thio CL, Nelson KE, et al. Knowledge of and attitudes towards hepatitis $B$ and its transmission from mother to child among pregnant women in Guangdong province. China PlosOne. 2017; 12(6):e0178671.

42. Rajamoorthy Y, Taib NM, Munusamy S, Anwar S, Wagner AL, Mudatsir M, et al. Knowledge and awareness of hepatitis $b$ among households in Malaysia: a community-based cross-sectional survey. BMC Public Health. 2019;19(47). https://doi.org/10.1186/s12889-018-6375-8.

43. Park B, Jung KW, Oh CM, Choi KS, Suh M, Jun JK, et al. Factors associated with alcohol consumption in hepatitis B carriers: a nationwide study in the Republic of Korea. PlosOne. 2014;9(11):e110144.

44. Pandis N. Cross-sectional studies. Am J Othrod Detofacial Othrop. 2014;146: 127-9.

\section{Publisher's Note}

Springer Nature remains neutral with regard to jurisdictional claims in published maps and institutional affiliations.

\section{Ready to submit your research? Choose BMC and benefit from:}

- fast, convenient online submission

- thorough peer review by experienced researchers in your field

- rapid publication on acceptance

- support for research data, including large and complex data types

- gold Open Access which fosters wider collaboration and increased citations

- maximum visibility for your research: over $100 \mathrm{M}$ website views per year

At BMC, research is always in progress.

Learn more biomedcentral.com/submissions 